\title{
On the Relationships among Emotional Intelligence, Affective and Social Strategy Use, and Academic Achievement of Iranian EFL Learners
}

\author{
Mina Rastegar \\ English Dept, Shahid Bahonar University of Kerman, Kerman, Iran \\ Maliheh Karami \\ English Dept, Shahid Bahonar University of Kerman, Kerman, Iran
}

\begin{abstract}
The present study attempted to investigate any significant relationships among Iranian EFL learners' emotional intelligence (EI), their affective and social strategy use, and their academic achievement. 106 Iranian junior and senior EFL students at Kerman University participated in this study. To obtain the required data, the following questionnaires were utilized: Emotional Intelligence Scale (EIS) developed by Schutte et al. (1998) to measure EI, and the Strategy Inventory for Language Learning (SILL) designed by Oxford (1990) to determine the frequency of affective and social strategy use. The participants' GPAs were also used as a measure of their academic achievement. The following results were revealed. Significant positive relationships between the following pairs-- EI and affective strategy use; EI and social strategy use; EI and academic achievement; and affective and social strategy use were shown. nonetheless, no significant relationships were found between the participants' affective and social strategy use and their academic achievement. This study recommends that EFL learners increase their use of affective and social strategies which will help them improve their EI; moreover, developed EI will lead to greater academic achievement.
\end{abstract}

Index Terms-Emotional Intelligence (EI), affective strategy use, social strategy use, academic achievement, English as a Foreign Language (EFL)

\section{INTRODUCTION}

Intelligence as a general concept encompasses social and emotional factors besides the cognitive factors (Cantor \& Kihlstorm, 1987; Sternberg, 1985; Thorndike, 1920; Wechsler, 1943). Goleman (1995) stressed that, IQ contributes about 20 percent to the factors that determine life success, the rest is related to other factors including EI. EI refers to "the cooperative combination of intelligence and emotion" (Mayer, Salovey, \& Caruso, 2004, p. 197). Research has shown that EI provides the basis for competencies that are important in almost any job (e.g., Carmeli, 2003; Jordan, Ashkanasy, Hartel, \& Hooper, 2002). Recent research has also shown that in addition to work settings, emotional intelligence is also important for classrooms (Petrides, Frederickson, \& Furnham, 2004), and it may influence academic achievement in different ways. From another perspective, since language is a social behavior and involves the external expression of emotions, affective and social language learning strategies also play important roles in determining one's academic success.

Although considerable research has been done on students' EI and their academic success (e.g., Abisamra, 2000; Khajehpour, 2011; Rastegar, 2012), there has been little, if any, attention as to how EI affects the use of affective and social language learning strategies, which, in turn, might influence the learners' academic achievement. This study, therefore, aimed at exploring the relationships among EFL learners' EI, their ALLS and SLLS use, and their academic achievement in an Iranian context.

\section{A. Emotional Intelligence}

Gardner (1983) initially described multiple intelligences which paved the way for recognition of other intelligences such as emotional intelligence. The term emotional intelligence (EI), partly stemmed from Gardner's interpersonal and intrapersonal intelligences, was first introduced by Mayer and Salovey (1990). It was popularized then by Goleman's publication of the book Emotional Intelligence in 1995. Goleman (2001) introduced some studies showing that there are some other factors to make individuals with high intelligence less successful than those with average intelligence. These factors include another aspect of intelligence that Goleman called emotional intelligence. EI is the ability to perceive, understand, and manage one's emotions (Salovey, Hsee, \& Mayer, 1993; Salovey\& Mayer, 1990). Goleman (1995, P.34) defined EI as "abilities such as being able to motivate oneself and persist in the face of frustration, to control impulses 
and delay gratification; to regulate one's moods and keep distress from swapping the ability to think; to emphasize and to hope".

Regarding the models of EI, there are two main perspectives: ability model, which considers EI as a form of mental ability and hence a pure intelligence, and mixed model, which combines mental ability with personality characteristics such as well-being and optimism (Mayer, 1999). The only ability model of emotional intelligence is proposed by Mayer and Salovey (1990). There are also two mixed models proposed by Bar-On (2002) and Goleman (1998). Furthermore, there are several scales for measuring emotional intelligence used in scientific research that are not based on any of the aforementioned theories of EI. One of these scales is the Self-Report Emotional Intelligence Test (SREIT) developed by Schutte and colleagues (1998).

\section{B. Affective and Social Language Learning Strategies}

In the literature, language learning strategy (LLS) has been defined by many researchers. According to Rubin (1987), language learning strategies are "strategies that contribute to the development of the language system which the learner constructs and (which) affect learning directly" (p. 23). Oxford (1990) stated that "learning strategies are specific actions taken by the learner to make learning easier, faster, more enjoyable, more self-directed, more effective, and more transferable to new situations" (p.8).

There exist different classifications of language learning strategies in the literature. Three kinds of strategies which contribute directly or indirectly to language learning has been identified by Rubin (1981). This classification includes learning strategies, communication strategies, and social strategies. O'Malley, Chamot, Stewner-Manzanares, Russo, and Kupper (1985) have divided LLS into three main categories: metacognitive, cognitive, and socio-affective strategies. Moreover, Oxford (1990) made a distinction between direct and indirect strategies: Direct strategies require mental processing of the target language. There are three main groups of direct strategies: memory strategies, cognitive strategies and compensation strategies. Indirect strategies, on the other hand, include: metacognitive strategies, affective strategies and social strategies. Oxford's classification has been selected for this study.

Affective strategies are concerned with learners' emotions, attitudes, motivations and values. Oxford (1990) suggested that through affective strategies language learners can gain control over their attitudes, emotions, values, and motivations. She also suggested that good language learners are often the ones who know how to control their emotions and attitudes towards learning.

Social strategies refer to learner's communication with people who use the target language. Oxford (1990) asserted that, there are three sets of social strategies: (1) cooperating with others, (2) asking questions for clarification or verification and for correction, and (3) empathizing with others that includes developing cultural understanding and becoming aware of others' thoughts and feelings. Learners can use these strategies to establish the ability of selfdirected learning. If people use these strategies efficiently, they can learn by themselves and self-examine their own progress. Therefore, having proper learning strategies can improve learners and their language abilities.

\section{LITERATURE REVIEW}

\section{A. EI and Language Learning Strategies}

In this section, an overview of the previous researches that were considered relevant to the present investigation would be given. Hasanzadeh and Shahmohamadi (2011) carried out a research to study the relationship between EI and learning strategies. They found that there is a significant positive correlation between students' total emotional intelligence and learning strategies.

Heydari and Azari (2009) studied the relationship between EI and language learning strategy use with language proficiency levels of Ahvaz Azad university students. The result showed that there was a negative relationship between emotional intelligence and proficiency level. In addition, it was revealed that there was a positive relationship between language learning strategy use and language proficiency level of students.

Akbari and Hosseini (2008) tried to figure out the possible relationship between learners' multiple intelligences' scores and language learning strategies. The result of the study showed that there is low significant relationship between learners' MI and language learning strategies. According to their findings, there is a significantly positive correlation between MI and language proficiency as well. In his study of emotional intelligence and learning strategies, Aghasafari (2006) found considerable relationship between emotional intelligence and language learning strategies.

\section{B. EI and Academic Achievement}

The influence of emotional intelligence on students' academic achievement has been widely explored. MacCann, Fogarty, Zeidner, and Roberts (2011) and Rastegar (2012) carried out research projects and found that emotional intelligence was related to academic achievement: Students with higher levels of emotional intelligence were likely to gain higher levels of academic achievement.

In his investigation of the relationship among emotional intelligence, parental involvement and academic achievement, Khajehpour (2011) indicated that there is a significant relationship between emotional intelligence and academic achievement among the participants of the study. 
By the same token, Song, Huang, Peng, Wong, and Chen (2010) investigated Chinese college students and found support that EI can predict the academic performance of college students and the quality of their social interactions with peers. Parker, Summerfieldt, Hogan, and Majeski's (2002) study on the relationship between emotional intelligence and academic success, has reported that there is a positive relationship between emotional intelligence and academic achievement.

\section{Language Learning Strategies and Academic Achievement}

Research has supported the value of using LLS and has shown the regular use of such strategies by successful language learners (Oxford, Park-Oh, Ito, \& Sumrall, 1993). Successful language learners have a tendency to select appropriate strategies depending on the requirements of the language task (Chamot \& Kupper, 1989). The study carried out by Kummin and Rahman (2010) support the idea that there is a relationship between the use of metacognitive strategies and achievement in English. Abar and Locken (2010) in their study of 205 high-school students revealed that there was a positive relationship between learning strategy use and achievement. Ghiasvand (2010) also reported more frequent use of learning strategies among upper achievers.

$\mathrm{Wu}$ (2008) carried out a qualitative study on the use of LLS of 10 Chinese ESL learners studying at a vocational institute. Results showed that participants used a wide variety of metacognitive, cognitive, and social/affective LLS. Social/affective LLS were found to be more popular than metacognitive and cognitive LLS among these participants. Karami (2001) compared learning and study strategies between lower and upper achiever students. He found that upper achievers use learning strategies much more than the lower achievers. Mortazavizadeh (2000) also showed that upper achievers use learning strategies much more frequently.

As Oxford (1990) conjectured, the social and affective strategies are found less often in L2 research literature. She stated that there is a need for more research on affective and social LLS. Hence, the same reason inspired this study on the affective and social LLS and the following research questions were posed to be answered:

1. Is there any significant relationship between Iranian EFL learners' EI and their affective strategy use?

2. Is there any significant relationship between Iranian EFL learners' EI and their social strategy use?

3. Is there any significant relationship between Iranian EFL learners' EI and their academic achievement?

4. Is there any significant relationship between Iranian EFL learners' affective and social strategy use?

5. Is there any significant relationship between Iranian EFL learners' affective strategy use and their academic achievement?

6. Is there any significant relationship between Iranian EFL learners' social strategy use and their academic achievement?

\section{METHOdOLOGY}

\section{A. Participants}

The participants of this study consisted of 106 junior and senior EFL students at Kerman University. The participants' age ranged from 20 to 25 and there were 80 female and 26 male among the participants of the study. The rationale behind carrying out the study in an academic setting was due to its aim at finding out the relationship between EFL students' EI, ALLS and SLLS use, and their academic achievement.

\section{B. Instrumentation}

The following questionnaires were utilized to obtain the required data:

1. Self-Report Emotional Intelligence Test --SREIT (Schutte et al., 1998)

2. Strategy Inventory for Language Learning --SILL (Oxford, 1990)

\section{Self-report Emotional Intelligence Test (SREIT)}

EI was measured with the 33 items five-point likert scale self-report emotional intelligence test. This scale assesses emotional intelligence based on self-report responses to tapping the appraisal and expression of emotion in self and others, regulation of emotion in self and others, and utilization of emotions in solving problems. Participants responded to the items by indicating their degree of agreement to each of the 33 statements using a ranging from 1(strongly disagree) to 5 (strongly agree). Items 5, 28, and 33 are scored reversely. The range of the score of this scale is between 33 and 165. According to Schutte et al. (1998), the original test has demonstrated high internal consistency (Cronbach's $\alpha$ ranging from 0.87 to 0.90$)$, and a good test-retest reliability of 0.78 .

\section{Strategy Inventory for Language Learning (SILL)}

In order to determine the participants' frequency of affective and social strategy use, SILL was administered. This inventory consists of 50 items and is a five-point likert type scale ranging from 1 (never or almost never true of me) to 5 (always or almost always true of me). It is divided into six subscales: memory, cognitive, compensation, metacognitive, affective, and social. For the purpose of the present study the last two subscales, namely affective and social, each consisting of 6 items were utilized. Higher scores indicated higher levels of affective and social language learning strategy use. 


\section{E. Data Collection Procedures}

To collect the required data the scales, i.e., the SREIT and the SILL were distributed among the participants concurrently. They were given time to rate each item. Also, they were asked to write their GPAs as the measurement of their academic achievement. Moreover, their GPAs were also extracted from their records to ascertain the accuracy of their reports. The participants were assured that the gathered information would be used only for research purposes. Finally, the collected data was fed into the computer and then correlation analysis was performed utilizing SPSS Version 15.0 to explore the relationships among the sample's emotional intelligence, affective and social strategy use, and their academic achievement.

\section{RESULTS}

After analyzing the data, the researchers drew certain results. Table 1 presents the descriptive statistics of the variables of the study, namely EI, Affective Strategy, Social Strategy, and academic achievement.

TABLE1.

THE DESCRIPTIVE STATISTICS OF THE VARIABLES

\begin{tabular}{|l|l|l|l|l|l|l|l|}
\hline & $\mathrm{N}$ & Range & Min & Max & Mean & SD & Variance \\
\hline EI & 106 & 66.00 & 92.00 & 158.00 & 123.94 & 15.72 \\
\hline ALLS & 106 & 24.00 & 6.00 & 30.00 & 17.83 & 4.00 \\
\hline SLLS & 106 & 20.00 & 10.00 & 30.00 & 20.27 & 4.17 \\
\hline GPA & 106 & 6.51 & 12.79 & 19.30 & 16.23 & 1.35 & 20.86 \\
\hline
\end{tabular}

To answer the research question posed for this research project, Pearson Product Moment Correlation was used. The analysis of the collected data revealed that there are significant correlation between the variables of the study. The results are shown in Table 2.

As can be seen in Table 2, the Pearson's correlation coefficient between students' EI and their affective language learning strategy use is 0.41 . Pearson's correlation coefficient between EI and SLLS use is 0.46. Moreover, Pearson's correlation coefficient between learners' EI scores and their GPAs is 0.22 . The results of correlational analysis of the participants' scores on affective and social LLS use revealed a correlation coefficient of 0.54. Furthermore, Pearson's correlation coefficient between ALLS use and achievement is 0.61. Finally, Pearson's correlation coefficient between SLLS use and academic achievement is 0.49 .

TABLE 2.

CORRELATION MATRIX OF THE VARIABLES

\begin{tabular}{|l|l|l|l|l|}
\hline & EI & Affective Strategy & Social Strategy & GPA \\
\hline EI & 1.000 & $.411^{* *}$ & $.467 * *$ & $.228^{*}$ \\
\hline Affective Strategy & $.411^{* *}$ & 1.000 & $.548^{* *}$ & .049 \\
\hline Social Strategy & $.467^{* *}$ & $.548^{* *}$ & 1.000 & .067 \\
\hline GPA & $.228^{*}$ & .049 & .067 & 1.000 \\
\hline
\end{tabular}

According to the results, it can be concluded that there were significant positive relationships between the following pairs: EI and affective strategy use; EI and social strategy use; EI and academic achievement; and affective and social strategy use. However, no significant relationships were found between the participants' affective and social strategy use and their academic achievement.

\section{DISCUSSION}

The first two research questions of this study sought to explore the existence of any relationship between EFL students' EI and their affective/social LLS use. The results indicated a significant positive correlation between learners' emotional intelligence and the frequency of their affective and social language learning strategy use. Based on the results, if EFL learners' emotional intelligence increases, their use of ALLS and SLLS also boosts. These findings are in line with those of the previous studies. Hasanzadeh and Shahmohamadi (2011), for example, stated that there is a significant positive relationship between students' total emotional intelligence and learning strategies. Similarly, Aghasafari's (2006) study found considerable relationship between emotional intelligence and language learning strategies. Moreover, Heydari and Azari (2009) confirmed these findings, reporting a positive relationship between language learning strategy use and EI.

The third research question asked whether there were any correlations between learners' EI and their academic achievement. As the results revealed, emotional intelligence and academic achievement were positively correlated among EFL learners who participated in this study. In line with many of the studies focusing on the construct of emotional intelligence that showed a positive relationship between EI and various measures of academic performance (e.g., Abisamra, 2000; Austin, Evans, Goldwater, \& Potter, 2005; Downey, Mountstephen, Lloyd, Hansen, \&Stough, 2008; Gil-Olarte Marquez, Martin, \& Brackett, 2006; Khajehpour, 2011; Lyons \& Schneider, 2005; MacCann et al., 2011; Parker et al., 2004; Qualter, Gardner, Pope, Hutchinson, \&Whiteley, 2012; Song et al., 2010), the findings of the 
present study indicated that those learners who have higher EI scores show higher academic achievement than those who have lower EI scores. However, the results of Heydari and Azari's (2009) study did not confirm the findings of the present study: their results showed that there was a negative relationship between emotional intelligence and proficiency level.

Regarding the relationship between EFL learners' affective and social LLS, the participants' use of ALLS and SLLS were found to be significantly correlated. It means that the EFL learners who had higher frequency of ALLS use also used SLLS more frequently. These findings are confirmed by the results reported by previous researchers. For example, Querol (2010) in his research indicated that affective LLS and social LLS were positively correlated. In other words, as the affective LLS are utilized so are the social LLS. "Both affective LLS and social LLS are therefore expected to be observed together as supported by O'Malley and Chamot's (1990) taxonomy of LLS that classifies affective and social LLS as one" (Querol, 2010, p.32).

The last two research questions in this study investigated the existence of any relationships between EFL learners' affective and social strategy use and their academic achievement. The results showed that there was no significant correlation between the two. In other words, in this study the participants' academic achievement did not depend on their use of affective and social language learning strategies. The findings of this study were in contrast to those of previous researches. Querol's(2009) study indicated that LLS proved significantly related to academic performance. All in all, most of previous studies have indicated a positive relationship between LLS use and language proficiency (e.g., Ababaaf , 2000; Abar \& Locken, 2010; Adamzadeh, 2001; Chamot \& Kupper, 1989; Ghiasvand, 2010; Green \& Oxford, 1995; Karami, 2001; Khaldieh, 2000; Kummin \& Rahman, 2010; Mortazavizadeh, 2000; Oxford et al.,1993; Samadi, 2004; Wharton, 2000; Wu, 2008).

\section{CONCLUSION}

The present study attempted to determine how emotional intelligence influences EFL students' use of affective and social LLS and how Iranian EFL learners' academic achievement is influenced by all these factors. It was concluded that a significant positive relationship exists between the following pairs: EI and affective strategy use; EI and social strategy use; EI and academic achievement; and affective and social strategy use. However, regarding affective and social strategy use and academic achievement no significant relationships were found. What these findings imply is that in educational contexts a great deal of attention should be paid to constructs such as EI and LLS, including affective and social strategies. In language learning contexts, attention to the aforementioned constructs can help the learners increase their abilities in different areas of language learning. To achieve such a goal, English teachers should become familiar with these constructs; moreover, they should try to raise the students' awareness about the constructs. In this way, the students can improve their language achievement. EFL learners do not usually pay heed to their social relationships and their feelings as part of the L2 learning process. Therefore, the ALLS and SLLS are ignored by many EFL learners. However, students that do not use these strategies should assisted.. As a result, EFL teachers and learners should try to develop strategy-based teaching and learning which will help them improve their EI, thus greater academic achievement will result.

\section{APPENDIX GRAPHS}

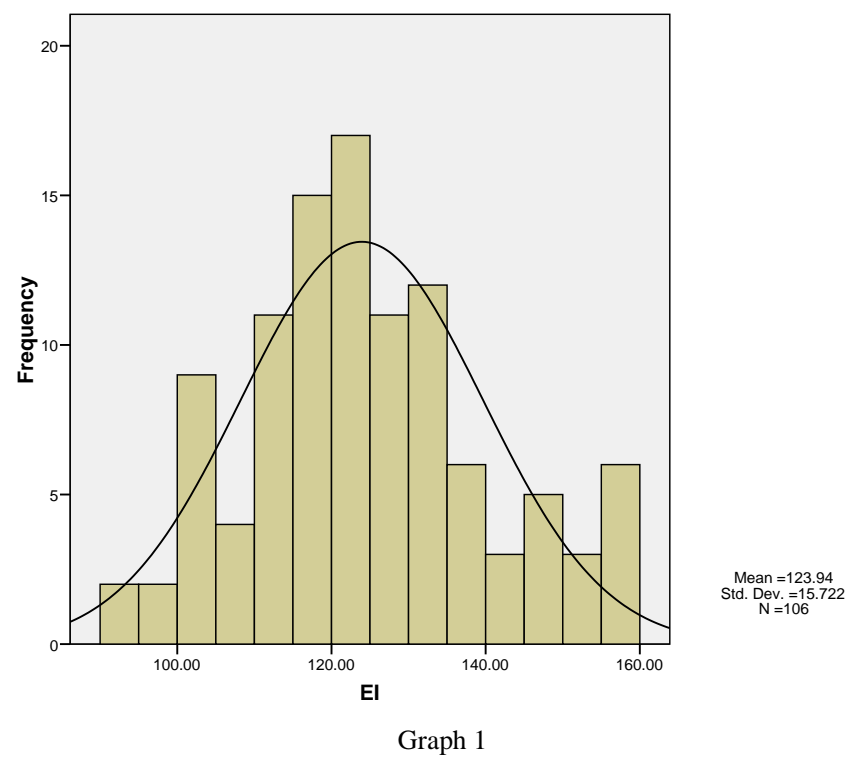




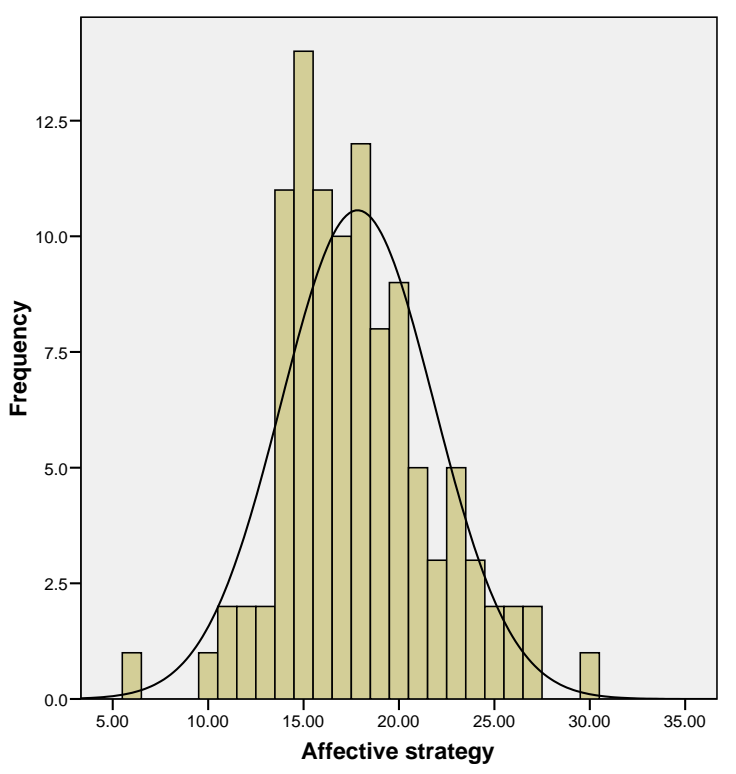

Mean $=17.83$
Std. Dev. $=4.004$
$N=106$

Graph 2

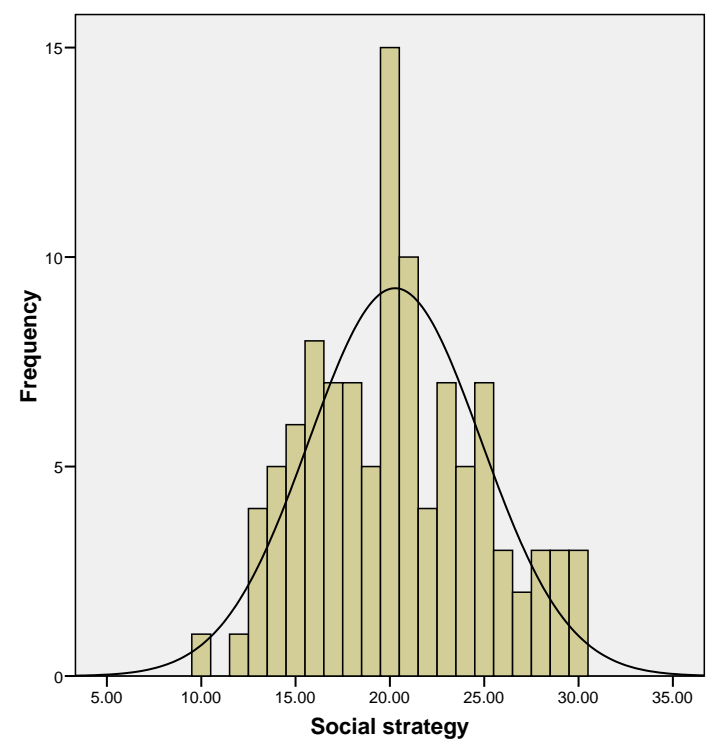

Mean $=20.27$
Std. Dev. $=4.568$
$N=106$

Graph 3

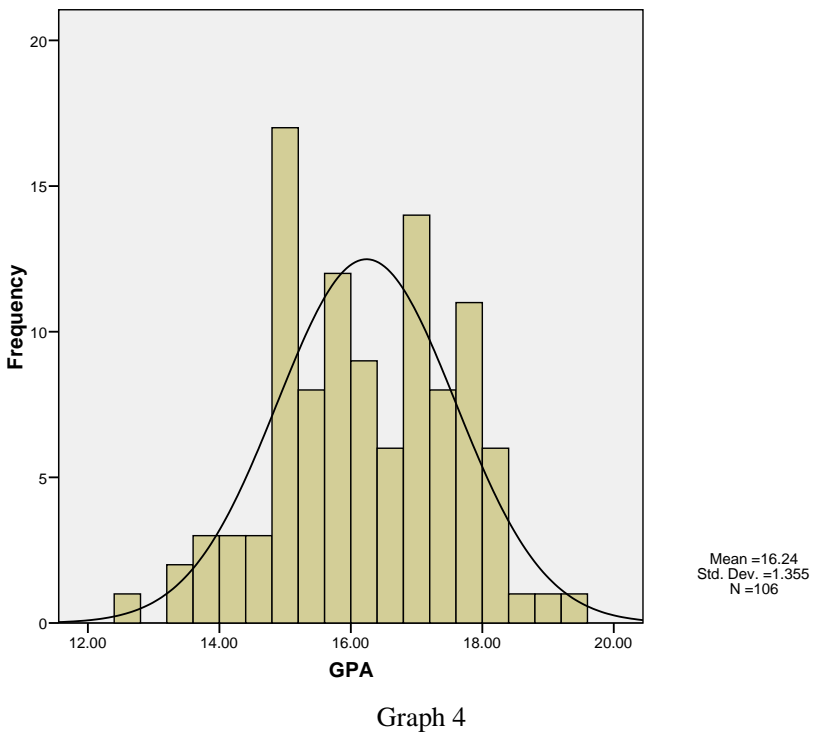




\section{REFERENCES}

[1] Ababaf. Z. (2000).Comparison between low and high achiever students in Tehran schools. (MA dissertation). Allameh Tabatabaei University, Iran.

[2] Abar, B., \&Locken, E. (2010). Self-regulated learning and self- directed study in a pre-college sample. Learning and Individual Differences, 20(1), 25-29.

[3] Abisamra, N. (2000). The relationship between emotional intelligent and academic achievement in eleventh graders. Educational and Psychological Measurement, 63, 840-858.

[4] Adamzadeh, F. (2001). Effects of instruction cognitive strategies in modify problem of students with LD in writing.(MA dissertation). Allameh Tabatabaei University, Iran.

[5] Aghasafari, M. (2006). On the relationship between emotional intelligence and language learning strategies.(MA dissertation). Allameh Tabatabaei University, Iran.

[6] Akbari, R., \& Hosseini, K. (2008). Multiple intelligences and language learning strategies: Investigating possible relations. System, 36, 141-155.

[7] Austin, E. J., Evans, P., Goldwater, R., \& Potter, V. (2005).A preliminary study of emotional intelligence, empathy and exam performance in first year medical students. Personality and Individual Differences, 39, 1395-1405.

[8] Bar-On, R. (2002). Bar-On emotional quotient inventory (EQ-I): Technical manual. Toronto, Canada: Multi-Health Systems.

[9] Cantor, N., \& Kihlstrom, J. (1987). Personality and social intelligence. Englewood Cliffs, NJ: Prentice Hall.

[10] Carmeli, A. (2003). The relationship between emotional intelligence and work attitudes, behavior and outcomes. Journal of Managerial Psychology, 18, 788-813.

[11] Chamot, A.U. \& Kupper, L. (1989).Learning strategies in foreign language interaction. Foreign Language Annals, 22, $13-24$.

[12] Downey, L. A., Mountstephen, J., Lloyd, K., Hansen, K., \& Stough, C. (2008).Emotional intelligence and scholastic achievement in Australian adolescents. Australian Journal of Psychology, 60, 10-17.

[13] Gardner, H. (1983). Frames of mind: The theory of multiple intelligences. New York: Basic Books.

[14] Ghiasvand, M. Y. (2010). Relationship between learning strategies and academic achievement based on information processing approach. Procedia Social and Behavioral Sciences, 5, 1033-1036.

[15] Gil-Olarte Marquez, P. G., Martin, R. P., \& Brackett, M. A. (2006).Relating emotional intelligence to social competence and academic achievement in high school students. Psicothema, 18, 118-123.

[16] Goleman, D. (1995). Emotional intelligence. New York: Bantam.

[17] Goleman, D. (1998). Working with emotional intelligence. New York: Bantam.

[18] Goleman, D. (2001). The emotionally intelligence workplace. Jossey-Bass: San Francisco.

[19] Green, M., Oxford, R., (1995).A closer look at learning strategies, L2 proficiency and gender. TESOL Quarterly 29, $261-297$.

[20] Hasanzadeh, R., \& Shahmohamadi, F. (2011).Study of emotional intelligence and learning strategies. Procedia Social and Behavioral Sciences, 29, $1824-1829$.

[21] Heydari, K. Z., \& Azari, M. (2009). The relationship between emotional intelligence and language learning strategy use with language proficiency levels of students. Scientific Information Databases, 3(9), 95-114.

[22] Jordan, P. J., Ashkanasy, N. M., Hartel, C. E., \& Hooper, G. S. (2002). Workgroup emotional intelligence: Scale development and relationship to team process, effectiveness, and goal focus. Human Resource Management Review, 12, 195-214.

[23] Karami, A. (2001). Providing instrument for assessing learning strategies.(Doctoral dissertation). AllamehTabatabaei university, Iran.

[24] Khajehpour, M. (2011). Relationship between emotional intelligence, parental involvement and academic performance of high school students. Procedia Social and Behavioral Sciences, 15, 1081-1086.

[25] Khaldieh, S.A. (2000). Learning strategies and writing processes of proficient vs. less-proficient learners of Arabic. Foreign Language Annals, 33 (5), 522-533.

[26] Kummin, S., \& Rahman, S. (2010). The relationship between the use of metacognitive strategies and achievement in English. Procedia Social and Behavioral Sciences, 7(C), 145-150.

[27] Lyons, J. B., \& Schneider, T. R. (2005).The influence of emotional intelligence on performance. Personality and Individual Differences, 39, 693-703.

[28] MacCann,C., Fogarty,G. J., Zeidner, M., \& Roberts, R. D. (2011). Coping mediates the relationship between emotional intelligence (EI) and academic achievement. Contemporary Educational Psychology, 36, 60-70.

[29] Mayer, J. D., \& Salovey, P. (1990).Emotional intelligence. Imagination, Cognition and Personality, 9 (3), $185-211$.

[30] Mayer, J. D., Salovey, P., \& Caruso, D. R. (2004). Emotional intelligence: Theory, findings, and implications. Psychological Inquiry, 15(3), 197-215.

[31] Mayer, J.D. (1999). Emotional intelligence: Popular or scientific psychology? APA Monitor, 30, 50.

[32] Mortazavizadeh, S. H.(2000). Comparison between learning and study strategies in lower and higher achiever students.(MA dissertation).AllamehTabatabaeiuniversity, Iran.

[33] O' Malley, J.M., Chamot, A.U. Stewner-Manzanares, G. Russo, R.P., \& Küpper, L. (1985). Learning strategy applications with students of English as a second language. TESOL Quarterly, 19, 557-584.

[34] O'Malley, J.M., \& Chamot, A.U. (1990). Learning strategies in second language acquisition. New York: Cambridge University Press.

[35] Oxford, R. (1990). Language learning strategies: What every teacher should know. Boston: Heinle \& Heinle.

[36] Oxford, R.L., Park-Oh, Y., Ito, S., \& Sumrall, M. (1993). Learning Japanese by satellite: What influences student achievement? System, 21, 31-48.

[37] Parker, J. D. A., Creque, S., Barnhart, D. L., Harris, J. I., Majeski, S. A., Wood, L. M., et al. (2004). Academic achievement in high school: Does emotional intelligence matter? Personality and Individual Differences, 37, 1321-1330.

[38] Parker, J. D. A., Summerfield, L. J., Hogan, M. J., \& Majeski, S. (2002). Emotional intelligence and academic success: Examining the transition from high school to university. ERIC Clearing House. 
[39] Petrides, K. V., Frederickson, N., \&Furnham, A. (2004). The role of trait emotional intelligence in academic performance and deviant behavior at school. Personality and Individual Differences, 36, 277-293.

[40] Qualter, P., Gardner, K. J., Pope, D. J., Hutchinson, J. M., \&Whiteley, H. E. (2012). Ability emotional intelligence, trait emotional intelligence, and academic success in British secondary schools: A 5 year longitudinal study. Learning and Individual Differences, 22, 83-91.

[41] Querol, M. (2009). Language learning strategies and academic performance of secondary students in science: Their relationships to learner characteristics. (Master's Thesis).University of the Philippines, Diliman, Quezon City.

[42] Querol, M. B. (2010). College students' use of affective and social language learning strategies: A classroom-based research. Philippine ESL Journal, 5, 22-39.

[43] Rastegar, M. (2012). On the Relationship between Emotional Intelligence, IQ, Scholastic Ability and language Proficiency among Iranian EFL Learners. Research in Educational Systems. In Press

[44] Rubin, J. (1981). Study of cognitive processes in second language learning. Applied Linguistics, 11, 117-131.

[45] Rubin, J. (1987). Learner strategies: Theoretical assumptions, research history and typology. In A.Wenden \& J. Rubin (Eds.), Learner strategies in language learning (pp. 15-30).Prentice/Hall International, Englewood Cliffs, NJ.

[46] Salovey, P., \& Mayer, J. D. (1990). Emotional intelligence. Imagination, Cognition and Personality, 9, 185-211.

[47] Salovey, P., Hsee, C., \& Mayer, J. D. (1993).Emotional intelligence and the regulation of affect. In D. M. Wegner, \& J. W. Pennebaker (Eds.), Handbook of mental control (pp. 258-277). Englewood Cliffs, NJ: Prentice Hall.

[48] Samadi, M. (2004). Role of self- regulation strategies in mathematic problem solving of students. Quarterly of Educational Innovations, 7, 73-97.

[49] Schutte, N.S., Malouff, J.M., Hall, L.E., Haggerty, D.J., Cooper, J.T., Golden, C.J., et al. (1998).Development and validation of a measure of emotional intelligence. Personality and Individual Differences, 25, 167-177.

[50] Song, L. J., Huang, G., Peng, K. S., Wong, C. S., \& Chen, Z. (2010).The differential effects of general mental ability and emotional intelligence on academic performance and social interactions. Intelligence, 38, 137-143.

[51] Sternberg, R. J. (1985). Beyond the IQ: The Triarchic Theory of Human Intelligence. New York: Cambridge University Press.

[52] Thorndike, R. L. (1920). Intelligence and its uses. Harper's Magazine, 140, 227-235.

[53] Wechsler, D. (1943). Non-intellective factors in general intelligence. Journal of Abnormal and Social Psychology, 38, $101-103$.

[54] Wharton, G. (2000). Language learning strategy use of bilingual foreign language learners in Singapore. Language Learning, $50(2), 203-243$.

[55] Wu, M. M. (2008). Language learning strategy use of Chinese ESL learners of Hong Kong: Findings from a qualitative study. Electronic Journal of Foreign Language Teaching, 5(1), 68-83.

Mina Ratsegar has been an Assistant Professor of Language and Applied Linguistics in the language department of the University of Kerman for the last 26 years. Her professional expertise lies in the area of Psycholinguistics. Her research focuses on L2 learner factors - affective, cognitive, and personality. She is currently teaching research methods, methodology, testing, and advanced writing at both B.A and M.A levels.

Maliheh Karami received B.A. in English literature from Shahid-Bahonar University, Kerman, Iran, in 2007. At present, she is an M. A. student in TEFL working on her M.A. thesis project. Her current research interests include various aspects of English teaching and psycholinguistics. 